\title{
Inhibition of Ovulation Induced by Gonadotropin in Immature Rats
}

\author{
Masami OZAKI, Takashi KUBO and Keiichi KURACHI \\ Department of Obstetrics and Gynecology, Osaka University, Medical School, Osaka, Japan
}

Recently, many studies have been reported concerning the action mechanism of hormones, though the action mechanism of gonadotropin, especially the mechanism of ovulation induced by gonadotropin is not yet well known partially because of difficulty in purification. It was reported in our previous report that the synthesis of RNA, protein and DNA was increased in the ovary of immature rat after HCG administration.

In this paper, inhibition of ovulation was studied with cycloheximide or actinomycin to decide whether the enhancement of RNA and protein synthesis is an inevitable process in the ovary for ovulation. In order to clarify the role of catecholamines in the hypothalamo-pituitary system, studies on the ovulation after a single injection of PMS to immature rats were performed and then it was studied whether the RNA extracted from the ovary of rats treated with PMS exerts the biological action like PMS.

1) Female immature rats (Sprague Dawley strain, weighing $40 \sim 50 \mathrm{~g}$ ) were used as experimental animals. Rats were administered with PMS (30iu) and then HCG (10iu) about 40 hours after PMS. $200 \mu \mathrm{g} / 100 \mathrm{~g}$ b.wt. of cycloheximide or $100 \mu \mathrm{g} / 100 \mathrm{~g}$ b.wt. of actinomycin was intraperitoneally administered at different intervals from the hormone injection. Ovulations were detected with the Rowlands technique.

Ovulations were almost always inhibited when cycloheximide was administered from $30 \mathrm{~min}$. before HCG injection to 5 hours after HCG injection but when cycloheximide was administered thereafter, ovulations could not be inhibited. When cycloheximide was administered within 5 hours after PMS injection, a tendency that ovulations were inhibited could be detected.

When actinomycin was administered from $30 \mathrm{~min}$. before to 6 hours after PMS or HCG injection, ovulations were sometimes inhibited, but the ovuation rate was higher than in the case with cycloheximide administration. From these results, it was suggested that the ovulation was induced through the actions of RNA and protein which were synthesized after gonadotropin administration and the synthesis of RNA and protein inevitable for ovulation was finished within 5 6 hours after gonadotropin treatment.

When strophanthin $G$ as an ATPase inhibitor was systemically administered after gonadotropin injection, in all cases ovulations occurred and both the number of ova and weight of ovaries were higher than in the strophanthin untreated cases. From these results, the active transport of $\mathrm{Na}^{+}$or $\mathrm{K}^{+}$with ATPase is suggested not to be related with 
the mechanism of ovulation.

2) PMS (30iu) was administered to female immature rats of Sprague Dawley strain. Ovulations were investigated about 68 hours after PMS injection. When reserpine or nialamide was administered following the schedule shown in the Table, ovulations with a single injection of PMS were inhibited. And when reserpine and dopa were injected, there was a case where the ovulation occurred. From these results, the process in the hypothalamo-pituitary system which involves $\mathrm{LH}$ release is suggested to need a moderate dynamics of catecholamines.

3) RNA of the ovary of PMS treated rats was extracted after the Scherrer and Darnell hot phenol method. The RNA was intraperitoneally administered to the immature rats according to the schedule shown in the Table. HCG (10iu) was injected after RNA administration. Ovulations were investigated about 20 hours after HCG injection. Neither ovulations nor weight gain of ovary could be detected in all cases.

(See pp. 422 437) 


\title{
Hormone gene thesis の立場よりみた Gonadotropin
}

\section{誘発排卵に関す.る基礎的研究}

\author{
Inhibition of Ovulation Induced by Gonadotropins in Immature Rats
}

大阪大学医学部産婦人科教室

尾 崎 公已, 久保喬 士

倉 智 敬 一

（昭和47年 5 月 10 日受付）

PMS-HCG による未熟 rat 排卵に対する各種抑制剤の影響を検討した. actinomycin または cycloheximide を PMS または HCG 投与後 $5 \sim 6$ 時間以内に投与すると排卵抑制の傾向がみられた. こ のととから PMS, HCG は卵巣で RNA 合成, 蛋白合成を介してその生物学的作用を発揮するものと 推論した。一方, PMS 単独投与による未熟 rat の排卵は reserpine, nialamide 投与により抑制され, 中枢での適正な catecholamine の動態が LH release などの process に必要なととが示された.

\section{緒 言}

近年各種 hormone の作用機序についての理解が深められて来たが，蛋白系 hormone である gonadotropin については purification の困難さも手伝つて, steroid 系 hormone である estrogen などに比較する と末だ解明されない領域が多く残されている.

gonadotropin には下垂体から分必される follicle stimulating hormone (FSH), luteinizing hormone (LH), luteotropic hormone (LTH) があつて, 卵胞の成熟, 排卵, 黄体化をつかさどる一方, 卵巣での steroidogenesis をも調節している。胎盤性の gonadotropin である pregnant mare's serum gonadotropin (PMS-G) は FSH 様作用を, human chorionic gonadotropin (HCG) は LH 様作用を持ち実地臨床上排 卵の誘発に使用されている。

著者らは最近 hormone の作用機序に関して hormone gene thesis に沿つて研究を進め, HCG 投与後 ラット卵巣において RNA 合成, 蛋白合成，DNA 合成が順に促進されることを見出し，それらの合成促 進が actinomycin D 投与によつて阻止される事実から，HCG は少くともその一部は gene transcription の step で作用するものであろうと結論しだ1).

本論文では gonadotropin 投与後の核酸, 蛋白質合成の促進が hormone 作用の本筋と関係するものであ れば，核酸および蛋白質合成の阻害剂を投与することによつて gonadotropin の生物学的作用の一つである 排卵現象が抑制されるという想定のもとに，主として RNA 合成阻害剂 actinomycin (act.) 蛋白合成阻害 剂 cycloheximide (cycl.) を用いてラットの誘発排卵に対する抑制効果を検討した. また一方，ラットでは PMS 単独投与によつて排卵を起し得るが，乙の際間脳下垂体系の関与を確める意味で reserpine や nialamide を用いて PMS 単独排卵に対する影響を検討した. Segal ${ }^{2)} ら は$ estrogen 処理ラット子宮から抽出し た RNA に去勢ラット子宮に対する estrogen 効果が認められたと報告しているが，著者らは PMS 処理 ラット卵雀から抽出した RNA の卵胞成熟能の有無について検討を加えた。 


\section{第 1 章 未熟ラットにおける PMS HCG 排卵に対する各種抑制剂の影響について}

\section{材料並びに方法}

実験動物としては生後約 4 週の Sprague Dawley 系未成熟雌ラットを使用した.

PMS としては Serotropin (帝国蔵器), HCG としては Pregnyl (Organon) または Primogonyl (Schering) を使用した. actinomycin は Actinomycin $\mathrm{S}_{2}$ (Daiichi Pure Ghemicals), cycloheximide は Nakarai Chemicals のものを使用した.

実験の大部分では PMS 30iu をラットの頸部皮下に投与し，その後約42時間で HCG 10iu を頸部皮下 に再び投与し，その約20時間後に開腹した。 卵巣と卵管を同時に剔出し，Rowlands らの方法に準じて実体 顕微鏡 (Nikon) 下で排卵の有無を確かめ, 一匹あたりの卵子数を算定した ${ }^{3) 4) . ~}$

一定量の actinomycin および cycloheximide を PMS あるいは HGG 投与と一定の時間間隔で腹腔内 に投与した. strophanthin G は $0.1 \mathrm{mg} / \mathrm{rat}$ を表中に示す schedule で投与した.

成 績

1) PMS 量, HCG 量とラット排卵との関係

PMS を 10iu, 20iu, 30iu, HCG を 5iu, 10iu, 20iu, 30iu, 投与した際の排卵の有無, 卵子数, 卵巣重量

Table 1. Induction of ovulation in the immature rats with PMSG-HCG

\begin{tabular}{c|c|c|c|c}
\hline $\begin{array}{c}\text { amount of } \\
\text { PMS-G (iu) }\end{array}$ & $\begin{array}{l}\text { amount of } \\
\text { HGG (iu) }\end{array}$ & ovulation rate & $\begin{array}{l}\text { No. of ova/rat } \\
{[ \pm \text { SE] }}\end{array}$ & $\begin{array}{l}\text { Wt. of ovary } \\
{[\mathrm{mg} \pm \text { SE] }}\end{array}$ \\
\hline 0 & 0 & $0 / 20$ & 0 & $6.9 \pm 0.3$ \\
10 & 5 & $1 / 3$ & 4.0 & $17.2 \pm 0.9$ \\
10 & 10 & $4 / 7$ & $9.5 \pm 2.4$ & $15.7 \pm 2.5$ \\
20 & 10 & $5 / 5$ & $33.6 \pm 7.2$ & $32.4 \pm 2.6$ \\
30 & 5 & $5 / 5$ & $19.0 \pm 3.9$ & $40.3 \pm 3.3$ \\
30 & 10 & $13 / 13$ & $31.5 \pm 3.7$ & $50.9 \pm 2.9$ \\
30 & 20 & $5 / 5$ & $17.0 \pm 2.8$ & $46.5 \pm 2.0$ \\
30 & 30 & $2 / 2$ & $39.5 \pm 7.5$ & $48.2 \pm 2.9$ \\
\hline
\end{tabular}

を検討した. PMS 0iu, HCG 0iu の control 群には0/20 と排卵は認められず，PMS 10iu HCG 5iu で 1/3, PMS 10iu HGG 10iu で4/7 と排卵率は増加し, PMS 20iu HGG 10iu, PMS 30iu HGG 5iu, PMS 30iu HGG 10iu, PMS 30iu HCG 20iu, PMS 30iu HGG 30iu の各群では 5/5，5/5，13/13，5/5，2/2と 全例に排卵を認めた。卵子数は PMS 投与量 HCG 投与量の増加と共に増加する傾向はみられたが，ばら つきも大きく相関するとは云えなかつた。卵巣重量は PMS, HCG 量の増加と共に増量する傾向が認めら れた. (Table 1)

以下の実験では充分量という意味から PMS 30iu HCG 10iu を投与した.

\section{2) Strophanthin G 投与による排卵への影䱥}

ATpase の inhibitor strophanthin G \& PMS 投与後あるいは HGG 投与後に数回投与を重ねた. 投 与時期は Table 2 に示す如くである.

その結果，排卵率には影響なく，PMS 投与後から strophanthin G を投与した群も，HCG 投与後に strophanthin G を投与した群も共に5/5の排卵を示した. 卵子数は control 群31.5に対して 54.6, 43.4 と 増加し, 卵巣重量も contorol 群50.9亿対して87.3，66.2と増量した。 (Table 2)

3) PMS 投与と関連して蛋白質または RNA 合成阻害剂を投与した際の排卯へ影響

a) Cycloheximide 投与量との関係 
Table 2. Effect of strophanthin-G injection on the PMS-HCG induced ovulation

\begin{tabular}{l|c|c|c}
\hline & ovulation rate & No. of ova/rat $[ \pm \mathrm{SE}]$ & weight of ovary [mg $\pm \mathrm{SE}]$ \\
\hline \hline str-G inj. after PMS* & $5 / 5$ & $54.6 \pm 4.4$ & $87.3 \pm 3.1$ \\
str-G inj. after HGG** & $5 / 5$ & $43.4 \pm 5.0$ & $66.2 \pm 2.8$ \\
not treated with str-G & $13 / 13$ & $31.5 \pm 3.7$ & $50.9 \pm 2.9$ \\
\hline
\end{tabular}

*PMS (30iu)

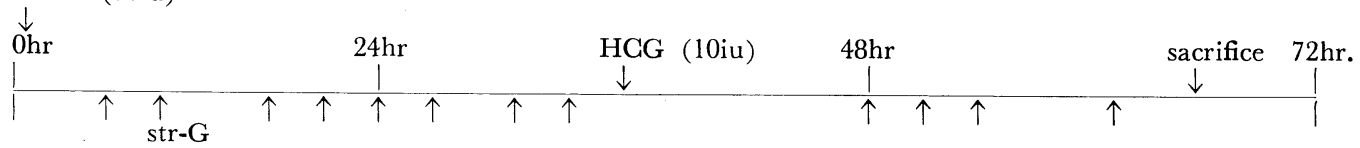

**PMS (30iu)

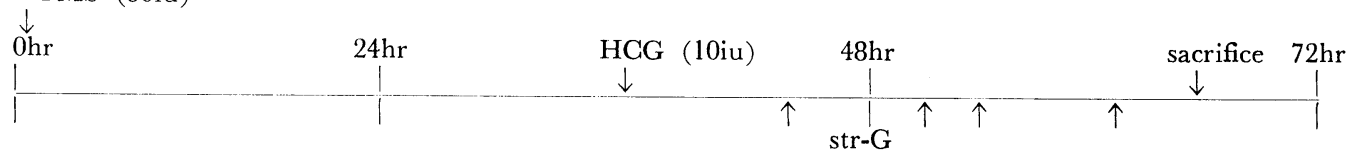

$0.1 \mathrm{mg} / \mathrm{rat}$ of strophanthin $\mathrm{G}$ was administered each times.

$100 \mu \mathrm{g} \sim 400 \mu \mathrm{g} / 100 \mathrm{~g}$ body weight の cycloheximide をPMS 投与前30分または PMS と同時に投与し て排卵への影響を検討した。 PMS 投与前30分に cycl. を投与した場合には排卵は抑制される傾向が認めら れ, cycl. 量を $100 \mu \mathrm{g} / 100 \mathrm{~g}$ b. wt. 200, 300, 400 と変動させると $1 / 3,3 / 7,2 / 3,0 / 1$ と排卵率は変動した が，cycl. 量の増加と共に 排卯率が減少する傾向はみられなかつた． PMS と cycl. の同時投与の場合は PMS 前30分の場合に比較して排卯率は高く, cycl. 量を100，200，300，400と変動させると排卵率は $3 / 3$, 2/4，5/7，3/3となり，cycl. 量と排卵率との間には一定の関係はみられなかつた。（Table 3) $300 \mu \mathrm{g} / 100 \mathrm{~g}$ b. wt. 以上の投与群では致死作用が認められたので 以後の実験では $200 \mu \mathrm{g} / 100 \mathrm{~g}$ b. wt. の cycl. を使用した。

\section{b) Gycloheximide 投与時期との関係}

Table 3. Effect of cycloheximide on the ovulation induced by PMS-G-and HCG (I)

\begin{tabular}{l|c|c|c}
\hline $\begin{array}{l}\text { Time and dosis of } \\
\text { cycloheximide } \\
\text { admistration }\end{array}$ & Ovulation rate & $\begin{array}{l}\text { No. ova/rat } \\
( \pm \mathrm{SE})\end{array}$ & $\begin{array}{l}\text { Weight of ovary } \\
(\mathrm{mg} \pm \mathrm{SE})\end{array}$ \\
\hline \hline 30min. & & & \\
before PMS inj. & & 0 & 34.0 \\
$400 \mu \mathrm{g} / 100 \mathrm{~g}$ b. wt. & $0 / 1$ & 3.5 & $32.0 \pm 3.1$ \\
$300 \mu \mathrm{g}$ & $2 / 3$ & $25.3 \pm 4.8$ & $28.3 \pm 1.3$ \\
$200 \mu \mathrm{g}$ & $3 / 7$ & 26.0 & $25.4 \pm 5.0$ \\
$100 \mu \mathrm{g}$ & $1 / 3$ & & $48.0 \pm 2.8$ \\
Simultaneous inj. & & $18.0 \pm 2.3$ & $44.0 \pm 3.5$ \\
with PMS & $3 / 3$ & $24.4 \pm 6.1$ & $32.4 \pm 2.8$ \\
$400 \mu \mathrm{g} / 100 \mathrm{~g}$ b.wt. & $5 / 7$ & 3.5 & $45.6 \pm 6.4$ \\
$300 \mu \mathrm{g}$ & $2 / 4$ & $21.0 \pm 3.2$ & \\
$200 \mu \mathrm{g}$ & $3 / 3$ & & \\
$100 \mu \mathrm{g}$ & & & \\
\hline
\end{tabular}

PMS (30iu) and HCG (10iu) were administered. 
Table 4. Effect of cycloheximide on the ovulation induced by PMS-G and HCG (II)

\begin{tabular}{l|c|c|c}
\hline $\begin{array}{l}\text { Time of cycloheximide } \\
\text { administration }\end{array}$ & Ovulation rate & $\begin{array}{l}\text { No. of ova/rat } \\
( \pm \mathrm{SE})\end{array}$ & $\begin{array}{l}\text { Weight of ovary } \\
(\mathrm{mg} \pm \mathrm{SE})\end{array}$ \\
\hline \hline $\begin{array}{l}\text { 30min. } \\
\text { before PMS inj. }\end{array}$ & $3 / 7$ & $25.3 \pm 4.8$ & $28.3 \pm 1.3$ \\
$\begin{array}{l}\text { Simultaneous inj. } \\
\text { with PMS }\end{array}$ & $2 / 4$ & 3.5 & $32.4 \pm 2.8$ \\
$\begin{array}{l}\text { 2hr. } \\
\text { after PMS inj. }\end{array}$ & $2 / 5$ & 6.0 & $29.6 \pm 2.1$ \\
$\begin{array}{l}\text { 4hr. } \\
\text { after PMS inj. }\end{array}$ & $3 / 5$ & $9.7 \pm 3.7$ & $19.0 \pm 2.3$ \\
$\begin{array}{l}\text { 5hr. } \\
\text { after PMS inj. } \\
\text { 6hr. } \\
\text { after PMS inj. } \\
\text { 9hr. } \\
\text { after PMS inj. }\end{array}$ & $10 / 10$ & $15.1 \pm 2.3$ & $24.7 \pm 1.5$ \\
\hline
\end{tabular}

$200 \mu \mathrm{g} / 100 \mathrm{~g}$ b. wt. of cycloheximide,

PMS (30iu) and HCG (10iu) were administered.

$200 \mu \mathrm{g} / 100 \mathrm{~g}$ b. wt. の cycl. 投与時期を PMS 投与前 30 分から, PMS 投与後 9 時間に亘つて変動させて 検討した. Table 4 亿示す如く, cycl. 投与時期を PMS 前30分, 同時, 2 時間後, 4 時間後, 5 時間後, 6 時間後， 9 時間後と変動させると排卵率は，3/7，2/4，2/5，3/5，3/5，10/10，3/4 と変動した.すなわ ち，PMS 投与後 5 時間以内に cycl. 投与した場合には排卵は抑制される傾向がみられたが，それ以後の投 与群では 9 時間後で 4 例中 1 例に排卵が抑制された以外は全例に排卵が認められた。

\section{c) Actinomycin 投与と排卵抑制}

$100 \mu \mathrm{g} / 100 \mathrm{~g}$ b. wt. の act. を PMS 投与前または後に投与した結果，Table 5 に示す如く，PMS 前30

Table 5. Effect of actinomycin on the ovulation induced by PMS-G and HCG

\begin{tabular}{l|c|c|c}
\hline $\begin{array}{l}\text { Time of actinomycin } \\
\text { administration }\end{array}$ & Ovulation rate & $\begin{array}{l}\text { No. of ova/rat } \\
( \pm \mathrm{SE})\end{array}$ & $\begin{array}{l}\text { Weight of ovary } \\
(\mathrm{mg} \pm \mathrm{SE})\end{array}$ \\
\hline \hline 30min. before PMS inj. & $4 / 6$ & $21.2 \pm 11.5$ & $24.4 \pm 3.0$ \\
2hr. after PMS inj. & $2 / 5$ & 12.5 & $12.0 \pm 2.9$ \\
4hr. after PMS inj. & $5 / 5$ & $10.2 \pm 5.1$ & $16.7 \pm 5.1$ \\
6hr. after PMS inj. & $2 / 5$ & 21.3 & $20.6 \pm 2.0$ \\
\hline
\end{tabular}

$100 \mu \mathrm{g} / 100 \mathrm{~g}$ b. wt. of actinomycin was administered, 30iu of PMS and 10iu of HCG were used

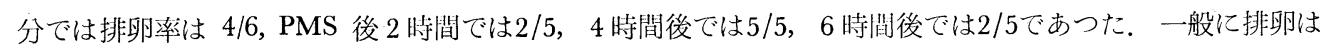
抑制される傾向がみられたが，投与時期との関係は明らかでなく，排卵抑制率も低值を示した。

4) HCG 投与と関連して蛋白質または RNA 合成阻害剂を投与した際の排卵への影響

a) Cycloheximide 投与量との関係

HCG 投与前 30 分に cycl. を投与した. cycl. 量を50，100，200，300，400，500と増加すると1/2，2/3， 0/8，0/2，0/2，0/2の排卯率を示した（Table 6) $200 \mu \mathrm{g} / 100 \mathrm{~g}$ b. wt. 以上の投与群には PMS-HCG によ る排卵は認められなかつた。 $300 \mu \mathrm{g}$ 以上の投与群では致死率が高かつたので，以下の実験では $200 \mu \mathrm{g} / 100 \mathrm{~g}$ 
Table 6. Effect of variable dosis of cycloheximide on the ovulation induced by PMS-Gand HCG

\begin{tabular}{c|c|c|c}
\hline $\begin{array}{l}\text { Dosis of cycloheximide } \\
(\mu \mathrm{g} / 100 \mathrm{~g} \text { b. wt. })\end{array}$ & Ovulation rate & $\begin{array}{l}\text { No. of ova/rat. } \\
( \pm \mathrm{SE})\end{array}$ & $\begin{array}{l}\text { Weight of ovary } \\
(\mathrm{mg} \pm \mathrm{SE})\end{array}$ \\
\hline \hline 500 & $0 / 2$ & - & $26.0 \pm 1.6$ \\
400 & $0 / 2$ & - & $32.8 \pm 1.0$ \\
300 & $0 / 2$ & - & $37.2 \pm 1.8$ \\
200 & $0 / 8$ & - & $26.4 \pm 1.6$ \\
100 & $2 / 3$ & 13.0 & $33.2 \pm 2.3$ \\
50 & $1 / 2$ & 36.0 & $15.5 \pm 7.9$ \\
0 & $13 / 13$ & $31.5 \pm 3.7$ & $50.9 \pm 2.9$ \\
\hline
\end{tabular}

Cycloheximide was administered $30 \mathrm{~min}$. before HCG injection.

PMS (30iu) and HCG (10iu) were used.

b. wt. の cycl. を投与した。卵巣重量は cycl. 非投与群に比較して cycl. 投与群では一般に低值を示した が，一定の增诚関係はみられなかつた。

\section{b) Cycloheximide 投与時期टの関係}

HCG 投与前 30 分から投与後 9 時間に亘つて cycl. を投与した結果を Table 7 亿示した.

HCG 投与前 30 分, HCG と同時, HCG 投与後30分， 1 時間， 2 時間， 3 時間，4 時間， 5 時間， 6 時

Table 7. Effect of cycloheximide on the ovulation induced by PMS-G and HGG

\begin{tabular}{l|c|c|c}
\hline \multicolumn{1}{c|}{$\begin{array}{c}\text { Time of cycloheximide } \\
\text { administration }\end{array}$} & Ovulation rate & $\begin{array}{l}\text { No. of ova/rat } \\
( \pm \mathrm{SE})\end{array}$ & $\begin{array}{c}\text { Weight of ovary } \\
(\mathrm{mg} \pm \mathrm{SE})\end{array}$ \\
\hline \hline 30min. before HCG inj. & $0 / 8$ & - & $26.4 \pm 3.7$ \\
Simultaneous inj. with HGG & $2 / 7$ & 12.0 & $36.9 \pm 3.1$ \\
30min. after HCG inj. & $0 / 5$ & - & $36.3 \pm 2.5$ \\
1hr. after HGG inj. & $0 / 5$ & - & $34.8 \pm 4.8$ \\
2hr. after HGG inj. & $0 / 5$ & - & $31.9 \pm 3.4$ \\
3hr. after HGG inj. & $0 / 5$ & - & $42.5 \pm 3.4$ \\
4hr. after HGG inj. & $0 / 5$ & - & $45.7 \pm 2.3$ \\
5hr. after HGG inj. & $1 / 6$ & 5.0 & $41.1 \pm 3.4$ \\
6hr. after HGG inj. & $6 / 9$ & $13.8 \pm 2.1$ & $51.8 \pm 3.9$ \\
9hr. after HGG inj. & $6 / 6$ & $13.8 \pm 5.6$ & $41.3 \pm 2.7$ \\
\hline
\end{tabular}

PMS (30iu) and HCG (10iu) were used.

$200 \mu \mathrm{g} / 100 \mathrm{~g}$ b. wt. of cycloheximide was administered.

間， 9 時間に cycl. を投与すると，排卵率はそれぞれ $0 / 8 ， 2 / 7 ， 0 / 5 ， 0 / 5 ， 0 / 5 ， 0 / 5 ， 0 / 5 ， 1 / 6 ， 6 / 9 ， 6 / 6$ となつた，HCG 投与後 5 時間以内に cycl. を投与すると，同時投与の際の $2 / 7 ， 5$ 時間後の $1 / 6$ 以外には排 卵はみとめられず，殆んど完全に cycl. は排卵を抑制した。卵巣重量と cycl. 投与時期との間には一定の変 動傾向はみられなかつた。

c) Actinomycin 投与による排卵抑制

HCG 投与前 30 分から HCG 投与後 9 時間住つて $100 \mu \mathrm{g} / 100 \mathrm{~g}$ b. wt. の actinomycin を投与した.

Table 8 亿示す如く, actinomycin の投与時期を HCG 投与前 30 分，投与後 1 時間， 2 時間， 4 時間， 6 時間， 9 時間と変動させると, 排卵率はそれぞれ7/8，4/5，5/5，2/3，4/8，4/4となつた。一般に。 cycl. 
Table 8. Effect of actinomycin on the ovalation induced by PMS-G and HGG

\begin{tabular}{l|c|c|c}
\hline $\begin{array}{c}\text { Time of actinomycin } \\
\text { administration }\end{array}$ & Ovulation rate & $\begin{array}{l}\text { No. of ova/rat } \\
( \pm \mathrm{SE})\end{array}$ & $\begin{array}{l}\text { Weight of ovary } \\
(\mathrm{mg} \pm \mathrm{SE})\end{array}$ \\
\hline \hline 30min. before HCG inj. & $7 / 8$ & $19.1 \pm 4.0$ & $39.2 \pm 2.1$ \\
1hr. after HCG inj. & $4 / 5$ & $34.3 \pm 3.4$ & $43.9 \pm 4.8$ \\
2hr. after HCG inj. & $5 / 5$ & $31.6 \pm 7.3$ & $51.0 \pm 3.8$ \\
4hr. after HCG inj. & $2 / 3$ & 11.5 & $22.0 \pm 2.1$ \\
6hr. after HCG inj. & $4 / 8$ & $29.7 \pm 8.1$ & $34.8 \pm 3.8$ \\
9hr. after HCG inj. & $4 / 4$ & $31.3 \pm 1.6$ & $39.1 \pm 4.1$ \\
\hline
\end{tabular}

PMS (30iu) and HCG (10iu) were used.

$100 \mu \mathrm{g} / 100 \mathrm{~g}$ b. wt. of cycloheximide was administered.

投与の場合と比較すると排卵抑制率は低かつたが，HGG 後 6 時間以内に act. を投与すると排卵は抑制さ れる傾向がみられた。

\section{第 2 章 未熟ラットに於ける PMS 単独排卵に対する中枢の関与について}

\section{実験方法}

実験動物として生後約 4 週の Sprague Dawley 系雌ラットを使用した。PS としてセロトロピン 30iu を頸部皮下に投与し，その後約68時間で開腹して排卵の有無を検索した。 また，reserpine $0.1 \mathrm{mg} / \mathrm{rat}$ また は nialamide $5 \mathrm{mg} / \mathrm{rat}$ を PMS 投与当日から 4 日間連日投与し, dopa は $5 \mathrm{mg} / \mathrm{rat}$ を投与した.

成 績

1) PMS 量とラット排卵との関係

PMS 量を 0,10,20,30iu と増加すると，排卵率は0/20，1/5，2/5，5/5と増加した。 (Table 9)

Table 9. Induction of ovulation in the immature rats with a single injection of PMS-G

\begin{tabular}{c|c|c|cc}
\hline $\begin{array}{l}\text { amount of PMS-G } \\
\text { (iu) }\end{array}$ & ovulation rate & $\begin{array}{l}\text { No. of ova/rat. } \\
( \pm \text { SE) }\end{array}$ & $\begin{array}{c}\text { weight of ovary } \\
(\mathrm{mg} \pm \mathrm{SE})\end{array}$ \\
\hline & & & ov $(+)$ & ov $(-)$ \\
0 & $0 / 20$ & 0 & - & 6.5 \\
10 & $1 / 5$ & 7.0 & 24.0 & 12.5 \\
20 & $2 / 5$ & 14.0 & 22.0 & 37.0 \\
30 & $5 / 5$ & $24.8 \pm 6.8$ & 54.2 & - \\
\hline
\end{tabular}

ov : ovulation

従つて以後の実験では PMS 30iu を投与した.

2) Reserpine, Nialamide または Dopa の PMS 単独排卵に対する影響

中枢抑制㓮として reserpine を Table 10 に示す schedule で投与すると，全例に抑卵はみとめられず， nialamide の場合には 5 例中 1 例にのみ排卵がみとめられた。 reserpine によつて低下した中枢の catecholamine 含量を dopa 投与によつて増加させると ${ }^{5)}$, Table 10 の(3)の schedule で dopa を投与した群で 7 例中 1 例に排卵が認められた。

3) Reserpine, Nialamide または Strophantgin G の PMS-HCG による排卵に対する影響

PMS HCG による誘発排卵に対する reserpine, nialamide 投与の影響を検討した成績を Table 11 亿示 した. nialamide, reserpine 投与の両群共, 全例に排卵が認められた。 
Hormone gene thesis の立場よりみた Gonadotropin 誘発排卵飞関する基礎的研究（尾崎，他） Table 10. Effects of reserpine, nialamide or dopa on the PMS-G induced ovulation

\begin{tabular}{l|c|c|cc}
\hline \multicolumn{1}{c|}{ drugs } & ovulation rate & $\begin{array}{l}\text { No. of ova/rate } \\
\text { rat ovulating }\end{array}$ & wt. of ovary (mg) \\
\hline & & & ov. (+) & ov. (-) \\
none & $5 / 5$ & $24.8 \pm 6.8$ & 54.2 & - \\
reserpine (1) & $0 / 5$ & 0 & - & 26.7 \\
reserpine +dopa (2) & $0 / 3$ & 0 & - & 24.8 \\
reserpine +dopa (3) & $1 / 7$ & 2.0 & 24.0 & 39.2 \\
nialamide (1) & $1 / 5$ & 15.0 & 33.0 & 32.3 \\
\hline
\end{tabular}

Schedule of drug administration

(1) PMS 30iu

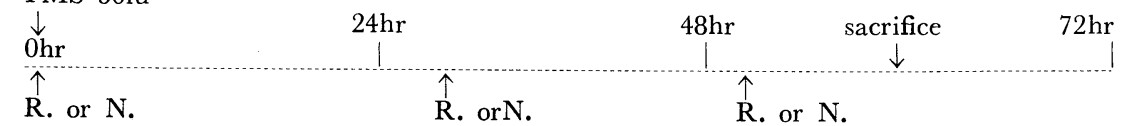

(2)

PMS 30iu

$\downarrow$

R.<smiles>[Mg][Mg][Mg]</smiles>

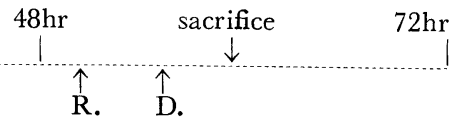

PMS 30iu

$\downarrow$<smiles>[R][13CH][13CH3]</smiles>

$\mathrm{R}$ : reserpine

$\mathrm{N}$ : nialamide

$24 \mathrm{hr}$ R.

R. D.

$0.1 \mathrm{mg} / \mathrm{rat}$ of reserpine, $5 \mathrm{mg} / \mathrm{rat}$ of dopa or $5 \mathrm{mg} / \mathrm{rat}$ of nialamide was administered each times.

Table 11. Effects of nialamide, reserpine or strophanthin-G on the PMS-G-HCG induced ovulation

\begin{tabular}{|c|c|c|c|c|}
\hline drugs & ovulation rate & $\begin{array}{l}\text { No. of ova/rat } \\
\text { ovulation }\end{array}$ & \multicolumn{2}{|c|}{ weight of ovary (mg) } \\
\hline & & & ov $(+)$ & ov $(-)$ \\
\hline none & $13 / 13$ & $31.5 \pm 3.7$ & $40.3 \pm 3.3$ & - \\
\hline nialamide (1) $(5 \mathrm{mg} / \mathrm{rat})$ & $3 / 3$ & $38.0 \pm 12.9$ & 43.4 & 36.0 \\
\hline reserpine $(1)(0.1 \mathrm{mg} / \mathrm{rat})$ & $3 / 3$ & $15.0 \pm 0.5$ & 34.0 & 35.5 \\
\hline strophanthin-G $(0.1 \mathrm{mg} / \mathrm{rat})$ & & & & \\
\hline after PMS (2) & $5 / 5$ & $54.6 \pm 4.4$ & 87.3 & - \\
\hline after PMS (3) & $5 / 5$ & $43.4 \pm 5.0$ & 66.2 & - \\
\hline
\end{tabular}

Schedule of drug administration

(1) $\mathrm{Ohr}$ PMS 30iu

$\uparrow \mathrm{N}$. or R.<smiles></smiles>

HCG 10iu $48 \mathrm{hr}$ $\uparrow$ N. or R.

sacrifice $\quad 72 \mathrm{hr}$ PMS 30iu<smiles>C1CC[Al]CC1</smiles><smiles>C1=C[As]C1</smiles>

PMS 30iu

(3) $\mathrm{Ohr}$

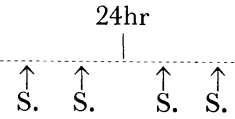

HCG 10iu 48hr

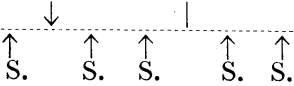

sacrifice

$72 \mathrm{hr}$

$24 \mathrm{hr}$

HCG 10iu 48hr $\uparrow$ S. $\uparrow$ S. $\uparrow$ S. $\uparrow \mathrm{S}$.

sacrifice $\quad 72 \mathrm{hr}$

$\mathrm{N}$ : nialamide

$\mathrm{R}$ : reserpine

S : strophanthin-G

第 48 巻 第 6 号 
strophanthin G を表中の schedule で投与すると卵巣重量は control 40.3mg に対して87.5mg, $66.2 \mathrm{mg}$ と増加し, 卵子数も control 31 に対して54, 43 と増加した。

\section{第 3 章 PMS 投与後の卵㫦より抽出した RNA による PMS 効果の発現について}

\section{実験方法}

PMS を未熟雌ラットに投与し，一定時間後に卵巣を剔出し，Scherrer \& Darnell の hot phenol 法6) そ準 じて RNA を抽出した7). 第 1 群の実験では PMS 投与後 3，6，12時間目の卵巣 RNA を, それぞれ別 の未熟雌ラット腹腔内に注射し，それぞれ RNA 注射後37，34，28時間後に HCG 10iu を注射して，そ の20時間後に排卵の有無を検索した. 第 2 群では, PMS 投与後 3，6，9，13，18，24時間目の卵巣 RNA を同一ラット腹腔内にそれぞれある時点より $3 ， 6 ， 9 ， 12 ， 18 ， 24$ 時間目に順に注射した．HCG 10iu を42時間目に投与して，その20時間目に開腹して排卵の有無を検索した.

成 績

Table 12, 13 に示した如く，いずれの方法によつても排卵は認められず，卵巣重量の増加もみられなか つた.

Table 12. Trial of induction of ovulation by RNA extracted from the ovary of rats administered with PMS-G (1)

\begin{tabular}{c|c|c}
\hline RNA source & Ovulation rate & Weight of ovary \\
\hline \hline Ovary 3hr. after PMS & $0 / 2$ & $6.6 \pm 0.69$ \\
Ovary 6hr. after PMS & $0 / 2$ & $6.6 \pm 0.62$ \\
Ovary 12hr. after PMS & $0 / 2$ & $8.0 \pm 0.58$ \\
\hline
\end{tabular}

10iu of pregnyl was used as HCG.

Table 13. Trial of induction of ovulation by RNA extracted from the ovary of rats administered with PMS-G (2)

The time after PMS injection, when RNA from the ovary or the liver was extracted.

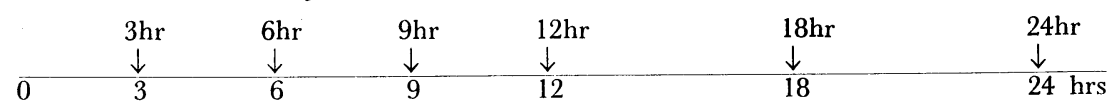

The time when the RNA was injected.

\begin{tabular}{c|c|c}
\hline RNA & Ovulation rate & Weight of ovary \\
\hline RNAs from ovary by turns & $0 / 2$ & $5.5 \pm 0.87$ \\
RNAs from liver by turns & $0 / 2$ & $8.6 \pm 0.95$ \\
\hline
\end{tabular}

10iu of pregnyl was used as HCG.

\section{考 察}

Gonadotropin の作用機序，特にその排卵を誘発する mechanism については増告も少く，未知の領域が 広く残されている，著者らは gonadotropin に対する卵巣の反応として RNA 合成，蛋白合成が促進され るととをすでに報告したが゙)，乙れらの促進については多くの報告がみられ間違いのない事実と思われる ${ }^{8) 99}$ 10). 一般にホルモンの作用機序に関して RNA 合成，蛋白合成の問題を究明する手段として，それらの合 成阻害剂によるホルモンの生物作用発現に対する影響をみる方法, いいかえれば消極的な方法がとられるて とが多い. 積極的な方法としてはホルモン投与後に誘導される RNA によつてホルモン作用を発揮させる 
方法などがあるが，かなりの問題点もあり今後に残された課題である。

著者らは両方向から検討を加えたが，まず gonadotropin の生物学的作用としては排卵現象を指標とし， PMS-HCG による未熟ラットの誘発排卵に対する actinomycin, cycloheximide 投与の影響を検討した。 そ の結果は成績のとてろに述べた様に，最も効果的に排卵が抑制されたのは HCG 投与前30分から HCG 投 与後 5 時間以内に cycloheximide を投与した場合で，殆んぞ完全に排卵は抑制された。それに対してHCG 投与後 6 時間以降の cycloheximide 投与では殆んど排卵は抑制されなかつた。一方, actinomycin を用い た場合には，排卵は抑制される傾向を認めたが，その抑制率は低值を示した。 また，時期的には HCG 投 与前 30 分から HCG 投与後 6 時間の間に actinomycin を投与した群では排卵抑制傾向が喼められた。しか し, actinomycin と cycloheximide 亿よる抑制効果の時間差から, gonadotropin の作用点が transcription, translation のいずれかを判定出来る程画然としたものではなかつた。また, actinomycin と cycloheximide による排卵抑制率の差から RNA 合成より蛋白合成の方が排卵にとつてより不可久だと結論するのは罗当 ではないと思われる。 actinomycin 投与によつて卵巣での HCG による蛋白質合成促進効果がおさえられ る事実，また，gonadotropin 投与によつて卵巣化新しい species の RNA が合成されて来るという我々の 成績（未発表）から，RNA 合成の占める意義は重大だと考えられ，actinomycin による抑制効果の低さは むしろその toxicity のため投与量に限界があることによるものと考宇ている.

PMS 投与に関連しての cycloheximide 投与実験の結果, PMS 前30分に投与した場合には排卵率は total では7/14で，半数に排卵抑制されたが cycloheximide 量を $100 \mu \mathrm{g}$ から $400 \mu \mathrm{g} / 100 \mathrm{~g}$ b. wt. に増加させて も排沺抑制率が上昇することはなかつた。 cycloheximide 投与時期を変化させると，PMS 後 5 時間目迄に 投与した場合には排卯は抑制される傾向がみられたが，HGG 投与に関連した場合の成績に比較すると抑制 率は低値を示した。 actinomycin 投与群にも排卵抑制の傾向はみられたが，投与時期と抑制率には一定の関 係はみられなかつた。乙れらの抑制剤による実験結果から，排卵に必要な PMS 効果は RNA 合成，蛋白 合成を通じて発現される可能性が認められた。排卵抑制率が低值を示したのはPMS 効果の持続が長いこと から抑制剤の効果が消失してから PMS 作用が発揮し始める可能性によるとも考えている，しかしての点に ついては別の手段によつて今後検討を要すると思われる。

PMS と HCG による folliculogenesis と ovulation 亿必須の RNA 合成，蛋白質合成の終了する時期 は，我々の成績からはいず机もそれらのホルモン投与後 5 〜 時間であつたが，ての点について Pool ら ${ }^{11)}$ は coitus 後 3 時間以内に家鬼卵胞内に actinomycin を注入すると排卵は抑制され，それ以後では無効であ つたと述べている. Barros ら ${ }^{12)}$ は未熟モルモットでは HCG 投与後 6 時間迄に $60 \mu \mathrm{g} / 100 \mathrm{~g}$ b. wt. の actinomycin を投与すると PMS-HCG による排卵は抑制されると報告している.

卵胞の成熟に付随して卵胞液が増加するが，乙の水分の眝溜と $\mathrm{Na}, \mathrm{K}$ イオンの膜透過性との関係を検討 する意味で $\mathrm{Na}^{+}{ }^{+} \mathrm{K}^{+}$の active transport に関与するといわれる ATpase の inhibitor である strophanthin G を投与してその排卵に及ぼす効果を検討したが，排卵を指標とした場合には抑制効果は認められず， むしろ卵子数，卵巣重量は増加した。 ATpase を抑制しても排卵は抑制されず，むしろ促進的な効果さえみ られたわけだがての mechanism は不詳である。

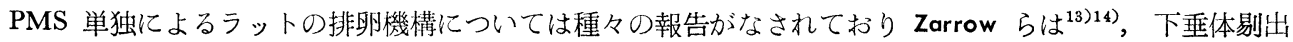
や chlorpromazine, dibenamine, atropin, nembutal 投与による排卵の抑制から中枢の関与を報告している. また，Meyerson ら ${ }^{15)}$ は脳内 catecholamine level を低下させる作用のある reserpine によるラット自然排 卵に対する抑制効果とその抑制効果が Monoamine oxidase inhibitor pargyline, nialamide 投与によつ て消失するてとから LH release のための中枢での process に catecholamine が関与すると報告している. Coppola $~^{16)}$ は未熟ラットに reserpine, $\alpha$ methyl dopa, syrosingopine あるいは tetrabenazine を投与す ると PMS 単独排卵を抑制すると報告し，脳内 norepinephrine level の低下によつて LH の合成または 放出が障害されると述べている，我々の成績からも reserpine によつて脳内 catecholamine の減少を来し た場合，MAO inhibitor nialamideによつて逆に増加させた場合共に PMS 単独排卵は抑制され，reserpine 


$$
\text { 日 本内分泌学会雑誌 }
$$

と dopa を併用した場合に，排卯のみられる場合のあつたてとから，PMS 単独排卵に必要な LH release には中枢での適正な catecholamine の動態が必要だと考えられる。 また, reserpine, nialamide によつて PMS-HCG による排卵を抑制出来ないてとから末梢での排卵機構には関係のないてとが判明した。

PMS 投与後のラット卵巣から抽出した RNA による排卵実験では RNAによるPMS 効果は認められ なかつた。しかし，乙れは PMS の作用機序に新合成の RNA が関係しないてとを意味するものではなく， 腹腔内に投与した RNA が RNase によつて分解されたのか, 完全な形の RNA が卵巣細胞内に移行し得 ないのか, または細胞内に移行しても polysome を形成して蛋白合成の鋳型となるてとが出来ないためとも 考えられ，今後ひきつづいて検討を要する問題である.

\section{結論}

未成熟メスラットに PMS 30iu と HCG 10iu を投与して排卵を誘発し，その排卵に対する蛋白合成阻 害剤 cycloheximide, RNA 合成阻害剤 actinomycin, ATpase 阻害剂 strophanthin G 投与の影響を検討 した.

PMS 投与に関連して阻害剤を投与した場合, str. G は排卵を抑制せず，むしろ卵子数の増加を示した。 cycl. は PMS 投与後 5 時間以内に用いると，排卵を抑制する傾向を示した。 actinomycin は投与時間の如 何にかかわらず一般に抑制の傾向を示したが抑制率は低值であつた．HCG 投与に関連して阻害㘊を投与し た場合, str. G は, PMS の場合と同様に, 排卵を抑制せず, むしろ卵子数, 卵巣重量の増加を示した。 cycl. は HCG 投与後 5 時間以内に用いると排卵を殆んど完全に抑制した。 act. は HCG 投与後 6 時間以 内に併用すると排卵を抑制する傾向が認められた。 てれらのととから PMS または HCG 投与後に誘導さ れる RNA 合成，蛋白合成は排卵機序に密接な関係があり，しかも排卵に必須のてれらの合成は gonadotropin 投与後 $5 \sim 6$ 時間以内に完了しているものと結論出来る. また，ATpase はよる電解質の active transport は排卵に積極的な意味を持たないものと考えられる.

一方, PMS 単独によるラットの排卵は reserpine, nialamide で抑制され, またこの LH release などの process には中枢での適正な catecholamine の動態が必要であるととを示した。

\section{文献}

1）尾崎公己, 倉智敬一：日内分泌会誌，47，226，(1971）.

2) Segal, S.J., O.W. Davidson, and K. Wada : Proc. Natl. Acad. Sci., 54, 782, (1965).

3) Rowlands, I.W. : Nature Lond. 150, 267, (1942).

4) Rowlands, I.W. : J. Endocrin. 3, 384, (1944).

5）倉智敬一：脳内活性アミン と性機能, 代謝（印刷中), 中山書店, 東京, (1972).

6) Sherrer, K. and J.E. Darnell, : Biochem. Biophys. Res. Commun., 7, 486, (1962).

7) Ozaki, M. and K. Kurachi : Acta Obst. \& Gyn. Jap. 18, 23, (1971). $\quad$ 8) VanDyke K. and P. A. Katzman : Endocrin, 83, 107, (1968). 9) Reel, J.R. and J. Gorski : Endocrin. 83, 1092, (1968). 10 10) Pool, W.R. and H. Lipner : Endocrin. 84, 711, (1969). $\quad 11)$ Pool, W.R. and H. Lipner : Nature London 203, 1385, (1964). 12) Barros G. and G.R. Austin : Endocrin. 83, 177, (1968). $\quad$ 13) Zarrow, M.X.and D.L. Quinn : J. Endocrin. 26, 181, (1963). 14) Quinn D.L. and M.X. Zarrow : Endocrin. 74, 309, (1964). 15) Meyerson B.J. and C.H. Sawyer : Endocrin. 83, 170, (1968). 16) Coppola J.A., R.G. Leonardi and W. Lippmann : Endocrin. 78, 225, (1966). 